\title{
Description of Culicoides (Mataemyia) felippebauerae sp. n., Forcipomyia musae immatures, and occurrence of $F$. genualis, breeding in banana stems in Brazilian Amazonia (Diptera: Ceratopogonidae)
}

\author{
Gustavo R Spinelli/+, María M Ronderos, Pablo I Marino, Daiane Silveira Carrasco*, \\ Ruth L Menezes Ferreira*
}

División Entomología, Museo de La Plata, Paseo del Bosque s/n, 1900 La Plata, Argentina *Instituto Nacional de Pesquisas da Amazônia, Manaus, AM, Brasil

The following three species of Ceratopogonidae were collected breeding in the rhizomatous herb Phenakospermum guyannense Endl., 1833 in the vicinity of Manaus, Brazil, a new species, Culicoides (Mataemyia) felippebauerae Spinelli, Forcipomyia (Forcipomyia) genualis (Loew), and F. (Phytohelea) musae Clastrier \& Dellécole. C. (M.) felippebauerae is described and illustrated as adult, pupa, and fourth instar larva, the adult compared with the adult of C. barthi Taveres and Souza and larva and pupa with those of C. dicrourus Wirth \& Blanton and C. macieli Tavares \& Ruiz, the only species with known immatures in the subgenus. The pupa and fourth instar larva of $\mathrm{F}$. (P.) musae are described and illustrated and compared with immatures of F. (P.) edwardsi Saunders.

Key words: Culicoides - Forcipomyia - biting midges - new species - immatures - "bananeiro" - Manaus

The Amazonian tropical rain forest houses a variety of small-sized vegetal substrates containing water. These microhabitats include treeholes, broken or damaged bamboo, axils of bromeliads, epiphytes, rotten banana stems, inflorescences, fruit husks, etc., in which breed, among other taxa, insects belonging to different families of Diptera (Fish 1976, 1983, Winder 1977). Among them, immatures of Ceratopogonidae are one the most conspicuous inhabitants of these environments (Fish \& Soria 1978, Wirth \& Soria 1981, Vitale et al. 1981, Fish 1983, Mercer et al. 2003).

Phenakospermum guyannense Endl., 1833 (Strelitziaceae) is a rhizomatous herb that can grow to $2 \mathrm{~m}$ or more tall. It is widely but patchily distributed in tropical South America; the leaves are large, alternate, and distichously arranged, differentiated into sheat, petiole, and blade. Large populations of this plant function as breeding habitats for insects, and are very common bordering roads in Amazonia, where they are commonly referred as "floresta de sororoca" (Ribeiro et al. 1999).

The purpose of this paper is to record three species of Ceratopogonidae recently collected in the axils of the "bananeiro" P. guyannense in the vicinity of Manaus, Brazil, to describe and illustrate a new species of Culicoides Latreille, as well as the larva of Forcipomyia (Phytohelea) musae Clastrier \& Dellecole and redescribe the pupa of this latter species.

\footnotetext{
+ Corresponding author: spinelli@fcnym.unlp.edu.ar Received 30 October 2006 Accepted 2 April 2007
}

\section{MATERIALS AND METHODS}

Immatures were collected near Manaus, Brazil, on BR-174 road, at km 31 (0208'58.7' $\left.\mathrm{S}, 60^{\circ} 00^{\circ} 05.9^{\prime \prime} \mathrm{W}\right)$, $\mathrm{km} 45\left(02^{\circ} 35^{\prime} 10.5^{\prime}\right.$ 'S, 6001'57.1'’ W), km 95 (0208'58.7'S, 6000'05.9"W), and km 123 (01'54'20.6"S, $60^{\circ} 03$ '41.1'”W).

The sheats of $P$. guyannense located in the pseudostem $30 \mathrm{~cm}$ above the ground were cut and plants were opened on a tray. Afterwards, the water with the immatures was collected inside plastic containers and carried to the laboratory. Larvae were observed daily to record amd monitor pupal development. Pupae were individually placed in small plastic cups, and were checked daily for emergence of adults.

Larvae were slide-mounted in Canada balsam, with their ventral side upward to facilitate examination of the epipharynx within the head capsule with a phase contrast microscope and oil immersion. Pupae and adults were also slide-mounted in Canada balsam, examined, measured, and drawn using a binocular microscope with camera lucida. Wing and scutum photomicrographs were taken with a Pentax Optio S 40, digital camera through a Leitz Wetzlar SM-LUX, binocular microscope.

Terminology of immatures follows Díaz et al. (2005) for Culicoides and Spinelli et al. (2005) for Forcipomyia. Terms for adult structures are those in the Manual of Nearctic Diptera (McAlpine et al. 1981), with the modifications for wing veins and cells proposed by Szadziewski (1996).

The holotype of the new species is deposited in the collection of the Instituto Nacional de Pesquisas da Amazônia (Inpa). Paratypes and other studied specimens are deposited in the collection of the Museo de La Plata, Argentina (MLPA). 


\section{RESULTS}

Culicoides (Mataemyia) felippebauerae Spinelli, n. sp. (Figs 1-30)

Diagnosis - Only species in the subgenus Mataemyia with one spermatheca. Male with stout, sinuate parameres with filiform tip; posteromedial projection of aedeagus tapered to slender, narrow, blunt tip, with a pair of well developed subapical points. Pupal respiratory horn with 8 apical spiracles.

\section{Description}

Male - Similar to female with the usual sexual differences. Wing (Fig. 1) length $0.87(0.83-0.90, \mathrm{n}=3)$ mm; width $0.31(0.30-0.32, \mathrm{n}=3) \mathrm{mm}$; CR $0.60(\mathrm{n}=3)$. Wing pattern similar to female, with distal pale spot in cell $\mathrm{r}_{3}$ broadly abbuting anterior wing margin; distal pale spot in cell $\mathrm{m}_{1}$ abbuting wing margin. Genitalia (Fig. 9). Tergite 9 long, with stout, triangular apicolateral processes, posteromedial margin slightly notched; sternite 9 with shallow posteromedial excavation. Gonocoxite elongate, with ventral root foot-shaped, the posterior heel not developed, dorsal root slender; gonostylus nearly straight, tapering gradually distally, apex abruptly curved $90^{\circ}$, sharply pointed. Parameres (Fig. 10) separate, each with slightly knobbed base; midportion stout, sinuate; distal portion bent laterally, narrowing to slender, simple, filiform tip that are ventrally directed. Aedeagus with high, rounded basal arch extending 0.50 of total length; basal arm slender, moderately recurved; posteromedial projection tapered abruptly to slender, narrow, blunt tip, with pair of lateral, well developed subapical points.

Female

Head - Dark brown. Eyes (Fig. 5) bare, separated by distance equal to diameter of one ommatidium. Flagellum (Fig. 6) brown, flagellomeres 2-12 vasiform, 9-12 more elongate than $2-8,13$ elongate with bluntly pointed tip; AR $0.94(0.88-0.97, \mathrm{n}=9)$; sensilla coeloconica on flagellomeres 1, 5-8. Palpus (Fig. 7) brown, third segment moderately swollen, with broad, shallow, subapical pit bearing capitate sensilla; PR 2.09 (2.00-2.23, $\mathrm{n}=4)$; $\mathrm{P} / \mathrm{H}$ ratio $0.63(0.54-0.73, \mathrm{n}=5)$. Mandible with $15-17$ teeth.

Thorax - Scutum and scutellum with markings as in photo (Fig. 2), major central area with broad, long, H-shaped mark. Legs dark brown; fore and midfemora with subapical, tibiae with subbasal pale rings, hind tibia pale distally; hind tibial comb with four spines, the second from the spur longest. Wing (Figs 3-4) length 1.07 $(0.96-1.20, \mathrm{n}=7) \mathrm{mm}$; width $0.49(0.43-0.56, \mathrm{n}=7)$ $\mathrm{mm}$; CR $0.66(0.64-0.67, \mathrm{n}=12)$; second radial cell and distal third of first radial cell in dark spot; pale spot over crossvein r-m large, broadly abutting costal wing margin; second radial cell elongate, with broad lumen; poststigmatic pale spot in cell $\mathrm{r}_{3}$ L-shaped, nearly isolating a small dark spot behind second radial cell; distal pale spot in cell $r_{3}$ oval, nearly filling apical portion of cell, usually not abbuting anterior wing margin (Fig. 3), but broadly abutting wing margin in some specimens (Fig. 4); cell $\mathrm{m}_{1}$ with two extensive, elongate pale spots, proximal one merges into transverse band of wing, distal one separated from wing margin by a short distance (Fig. 3), or abbuting wing margin in some specimens (Fig. 4); cell $\mathrm{m}_{2}$ with pale spot behind medial fork and with two distal pale spots, distal most one broadly abutting wing margin; cell cua ${ }_{1}$ with rounded pale spot broadly abutting wing margin; anal cell with two large distal pale spots. Macrotrichia scattered on distal third of wing, also a few present in cell cua ${ }_{1}$ and anal cell. Halter pale brown.

Abdomen - Brown, pleura of segments 1-7 darkish. One ovoid spermatheca (Fig. 8) with sclerotized neck, measuring $51(44-62, \mathrm{n}=4)$ by $40(34-44, \mathrm{n}=2) \mu$, neck $9(8-10, \mathrm{n}=4) \mu$; a sclerotized ring present.

Pupa - Female - Exuviae pale yellowish. Cephalothorax length $0.70(0.67-0.99, \mathrm{n}=3) \mathrm{mm}$, width $0.59(0.42-$ $0.78, \mathrm{n}=3) \mathrm{mm}$; cephalothoracic tubercles as follows: anterodorsal tubercle (ad) (Fig. 11) short, with two setae, one very short, 2nd much longer, slender; dorsolateral tubercle (dl) (Fig. 12) rounded, with two thin setae, one long, the 2nd of medium length, base rounded; dorsal tubercles (d) (Fig. 14) small: (i) with thin, medium length seta, (ii) with long, thin seta, (iii) with long, very thin seta, (iv) pore, (v) with minute seta; two short, thin ventromedian setae (vm) (Fig. 13); two ventrolateral thin setae (vl) (Fig. 13), one medium length, the 2nd long. Respiratory horn (Fig. 12) length 0.14 (0.12-0.16 n = 5) mm; dark brown, with scale-like pointed spicules along entire length but more abundant on basal half; with 2-3 lateral, 7-8 apical spiracles; pedicel very reduced, length $0.042(0.03-0.05, \mathrm{n}=5) \mathrm{mm} ; \mathrm{P} / \mathrm{H} 0.27(0.25-0.31, \mathrm{n}=$ 5). Operculum (Fig.15) slightly shorter than greatest breadth, apex blunt; surface with scattered rounded tubercles, proximal most ones pointed, anteriorly directed; anteromarginal tubercles (am) well developed, with single long, stout seta; basal sensillum short, thin; OL $0.116(0.11-0.12, \mathrm{n}=5) \mathrm{mm}$; OW $0.136(0.13-0.16, \mathrm{n}=$ 5) $\mathrm{mm}$; OW/OL $1.22(1.08-1.33, \mathrm{n}=5)$. Abdominal segments with sparse anterior spinules. Fourth abdominal segment (Fig. 16) with two dorsal anterosubmarginal tubercles (dasm): (i) with short, thin seta, (ii) with very long, thin seta; five dorsal posteromarginal tubercles (dpm): (i) with very short peg, (ii-iii) without seta, (iv) with minute seta, (v) with medium length, thin seta; three lateral posteromarginal tubercles (lpm) very well developed, all with base quadrangular base: (i) small-sized, with short, stout seta, (ii) stout, (iii) smaller than ii, (ii) with spur, (iii) with medium-sized, thin seta; one anterosubmarginal tubercle (lasm) very small, with minute seta; three ventral posteromarginal tubercles (vpm): (i) with short peg, (ii) with long, thin seta, (iii) with medium length, thin seta. Female caudal segment (Fig. 17) length $0.178(0.17-0.19, \mathrm{n}=5) \mathrm{mm}$, width $0.148(0.14-0.16, \mathrm{n}=5) \mathrm{mm}$, approximately as long as greatest breadth; ventral surface with anterior band of posteriorly directed spicules; dorsal surface with posteriorly directed spicules except laterally and on a mesal small closed area; posterolateral processes moderately developed, with inner spicules, tips pointed. Male caudal segment (Fig. 18) length $0.18 \mathrm{~mm}$, width $0.12 \mathrm{~mm}$; genital processes covered with ventral spicules on distal third. 


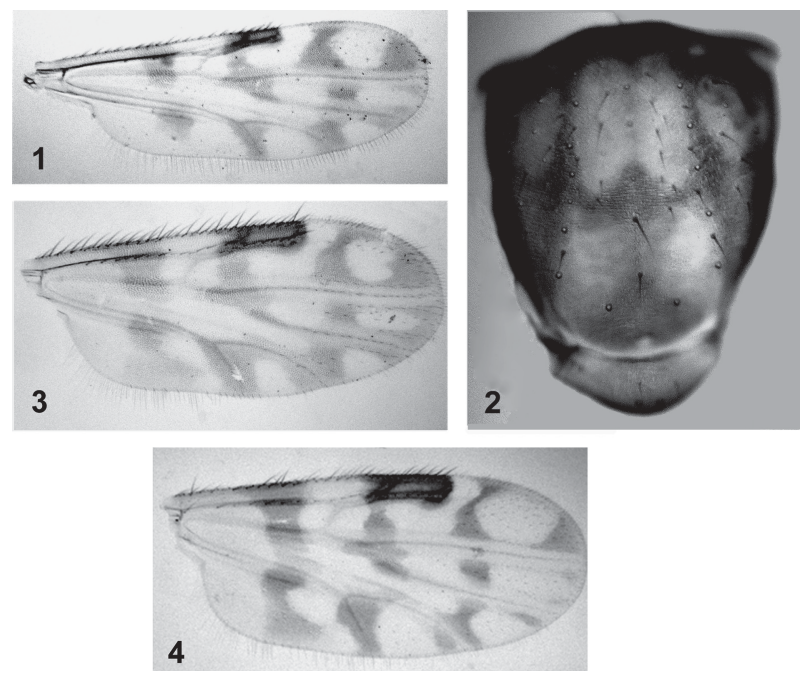

Culicoides felippebauerae - Fig. 1: male. Figs 2-4: female. Figs 1, 3-4: wing. Fig. 2: scutum and scutellum, dorsal view.

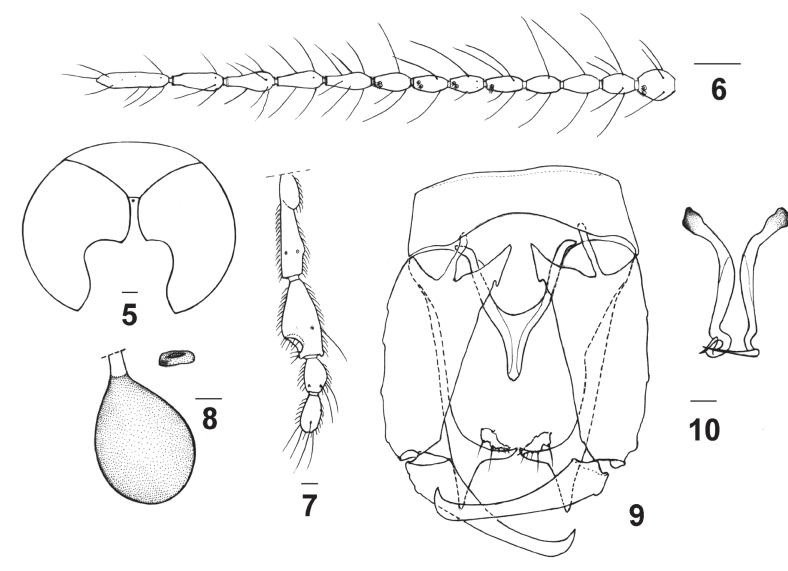

Culicoides felippebauerae - Figs 5-8: female. Figs 9-10: male. Fig. 5: head. Fig. 6: flagellum; Fig. 7: palpus. Fig. 8: spermatheca and ring. Fig. 9: genitalia (parameres removed). Fig. 10: parameres.

Larva - Head capsule (Figs 19-23) yellowish brown; elongated, slightly tapering to blunt apex; chaetotaxy as in Figs 20-22; HL $0.145(0.144-0.146 ; \mathrm{n}=2) \mathrm{mm}$; HW $0.976(0.965-0.987 ; \mathrm{n}=2) \mathrm{mm} ; \mathrm{HR} 0.148(0.147-0.149$; $\mathrm{n}=2)$; SGW $0.765(0.754-0.777 ; \mathrm{n}=2) \mathrm{mm}$; SGR 1.27 $(\mathrm{n}=2)$. Labrum (Figs 21-22, 25-26) membranous; palatum (Figs 21-23, 25-26) with two groups of three sensillae styloconica each, two pairs of sensillae chaetica, one immediately under the other, immediately underneath one pair of sensillae trichoidea; messors (Figs 25-26, 28) small, thin, well sclerotized; six well developed scopae (Fig. 28). Maxilla (Figs 25-27) sclerotized, with one long, thick, stout seta on galeolacinia; maxillary palpus (Fig. 27) cylindrical, with 3 papillae of different length (one long, two of medium length). Mandible (Figs 19, 25-27) large, broad at base, strongly sclerotized; length $0.040 \mathrm{~mm}$; one well defined, subapical, inner tooth; base wide with prominent, rounded point of articulation; one sensory pit, one seta on the aboral surface, both evident under SEM. Hypostoma (Figs 22-23, $25,28)$ with rounded, mesal elevation; 3-4 prominent lateral teeth. Epipharynx (Figs 19, 23) poorly massive, with two combs: dorsal comb sclerites with with 6 lanceolate, subequal teeth/sclerite; DCW $0.030 \mathrm{~mm}$; comb 4 massive, small, with 20 very small pointed teeth; each lateral arm membranous, without curtain or fringe; LAW $0.070 \mathrm{~mm}$. Hypopharynx (Figs 19, 23) short, lightly sclerotized; posterior end of each arm blunt, hypo-pharingeal fringe with 24-26 long, fine teeth.

Thoracic pigmentation yellowish, diffuse. Caudal segment (Figs 29-30) wide; CSL $0.327 \mathrm{~mm}$; CSW 0.178 $\mathrm{mm}$. One seta "o" $0.303 \mathrm{~mm}$ long, the other $0.357 \mathrm{~mm}$, one seta " $i$ " $0.191 \mathrm{~mm}$ long, the other $0.216 \mathrm{~mm}$; distance between bases of setae "o" subequal to the distance between bases of setae "i".

\section{Distribution - Brazil (Amazonas).}

Taxonomic discussion - C. felippebauerae is a member of the subgenus Mataemyia Vargas, and represents the first species in the subgenus with a single spermatheca. The only available key for Mataemyia was provided by Wirth and Soria (1981) (as discrepans group) for only 8 of the hitherto 15 recognized species in the subgenus (Borkent \& Spinelli 2000).

The adult of $C$. felippebauerae is very similar to $C$. barthi Tavares \& Souza from Rio de Janeiro, Brazil, from which it can be distinguished by the single spermatheca, longer second radial cell and tip of parameres without fringe. The wing patterns of $C$. azureus Wirth \& Blanton and C. mojingaensis W. \& B., both from Panama, are very similar to that of $C$. felippebauerae except for the shape of the distal pale spot in cell $\mathrm{r}_{3}$ (irregular in $C$. azureus, oval in C. mojingaensis).

The larva and pupa of only two species of the subgenus Mataemyia are presently known: $C$. dicrourus Wirth \& Blanton and C. macieli Tavarez \& Ruiz, which were described by Wirth and Soria (1981). The pupa of both species bear 25-30 spiracles on the respiratory organ, and the basal sensillum in the am tubercle lack setae. Additionaly, the pupa of $C$. dicrourus differs from that of $C$. felippebauerae in that the $\mathrm{dl}$ tubercle bears 3 setae. The descriptions of the larvae of $C$. dicrourus and C. macieli are very incomplete, so no comparison with the larva of C. felippebauerae is presently possible. However, the setae of the caudal segment of both species are shorter than those of $C$. felippebauerae.

Murphree and Mullen (1991) and Ronderos and Spinelli (2000) mentioned the same character states exhibited by larvae of tree-hole breeding species: diffuse yellowish brown thoracic pigmentation, large setae on the caudal segment, and extensive epipharyngeal lateral curtains. In the particular case of C. felippebauerae, which breeds in the axilla of $P$. guyannense, the larva exhibits the first two mentioned characters, whereas the epipharynx is devoid of curtains. The larva of $C$. 


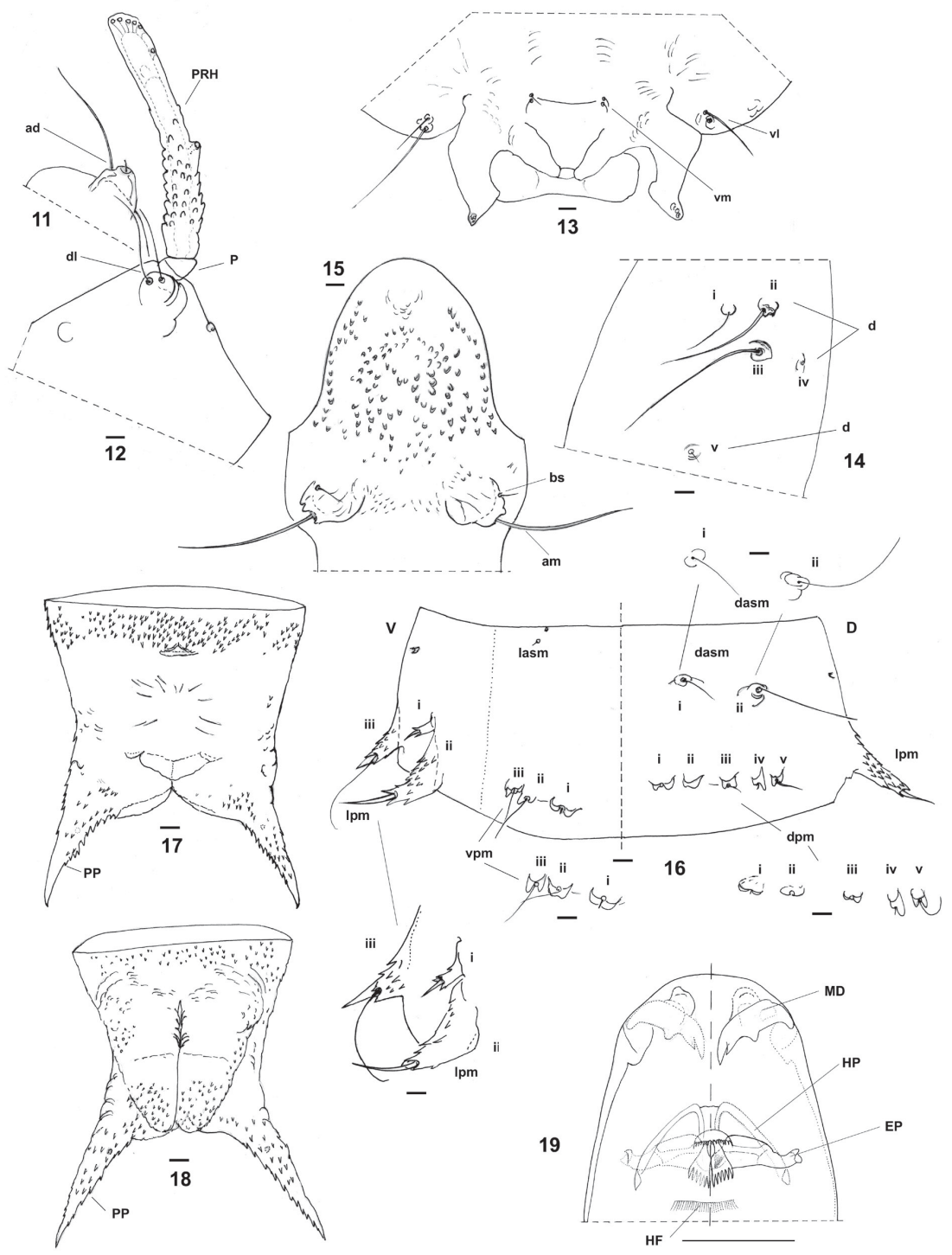

Culicoides felippebauerae - Figs 11-18: pupa. Fig. 19: larva. Fig. 11: anterodorsal tubercle (ad). Fig. 12: dorsolateral tubercle (dl), respiratory horn $(\mathrm{PRH})$, pedicel (P). Fig. 13: ventrolateral setae (vl), ventromedian setae (vm). Fig. 14: dorsal tubercles (d). Fig. 15: operculum, anteromarginal tubercle (am), basal sensillum (bs). Fig. 16: fourth abdominal segment, abdominal tubercles: lateral anterosubmarginal tubercle (lasm), dorsal posteromarginal tubercle (dpm), dorsal anterosubmarginal tubercle (dasm), ventral posteromarginal tubercle (lpm). Fig. 17: female caudal segment (ventral view). Fig. 18: male caudal segment (ventral view), posterolateral processes (PP). Fig. 19: head capsule, mandible (MD), epipharynx (EP), hypopharynx (HP).

felippebauerae exhibits characters typical of carnivorous species, such as an elongate head with the mouthparts directed anteriorly, a highly sclerotized labium, a lightly built pharynx, and broad, pointed, hooked mandible (Mullen \& Hribar 1988).

Types - Holotype male, allotype female (with pupal exuviae), Brazil, Amazonas, Manaus, km 123 BR 174, 29-VII-2005, D Carrasco. Paratypes, 3 males, 12 females, 1 larva, as follows; same data as holotype, 2 females (one with pupal exuviae); same data except 21VI-2006, 1 larva; same data except $\mathrm{km} \mathrm{45,} 1$ male, 1 female (with pupal exuviae); same data except $\mathrm{km} \mathrm{45,} \mathrm{4-}$ IX-2005, 4 females (3 with pupal exuviae); same data except km 95, 21-VI-2006, 2 males, 5 females.
Material examined by SEM - Brazil, Amazonas, Manaus, km 123 BR 174, 21-VI-2006, D Carrasco, 2 larvae.

Derivation of specific epithet - This species is named after our friend and colleague María Luiza Felippe-Bauer (Instituto Oswaldo Cruz, Rio de Janeiro) in recognition of her important contribution to the ceratopogonid taxonomy in the Neotropics.

Forcipomyia (Forcipomyia) genualis (Loew).

Ceratopogon genualis Loew, 1866: 128 (male; Cuba).

Ceratopogon propinqua Williston, 1896: 279 (male; St. Vincent).

Forcipomyia raleighi Macfie, 1938: 160 (male, fe- 

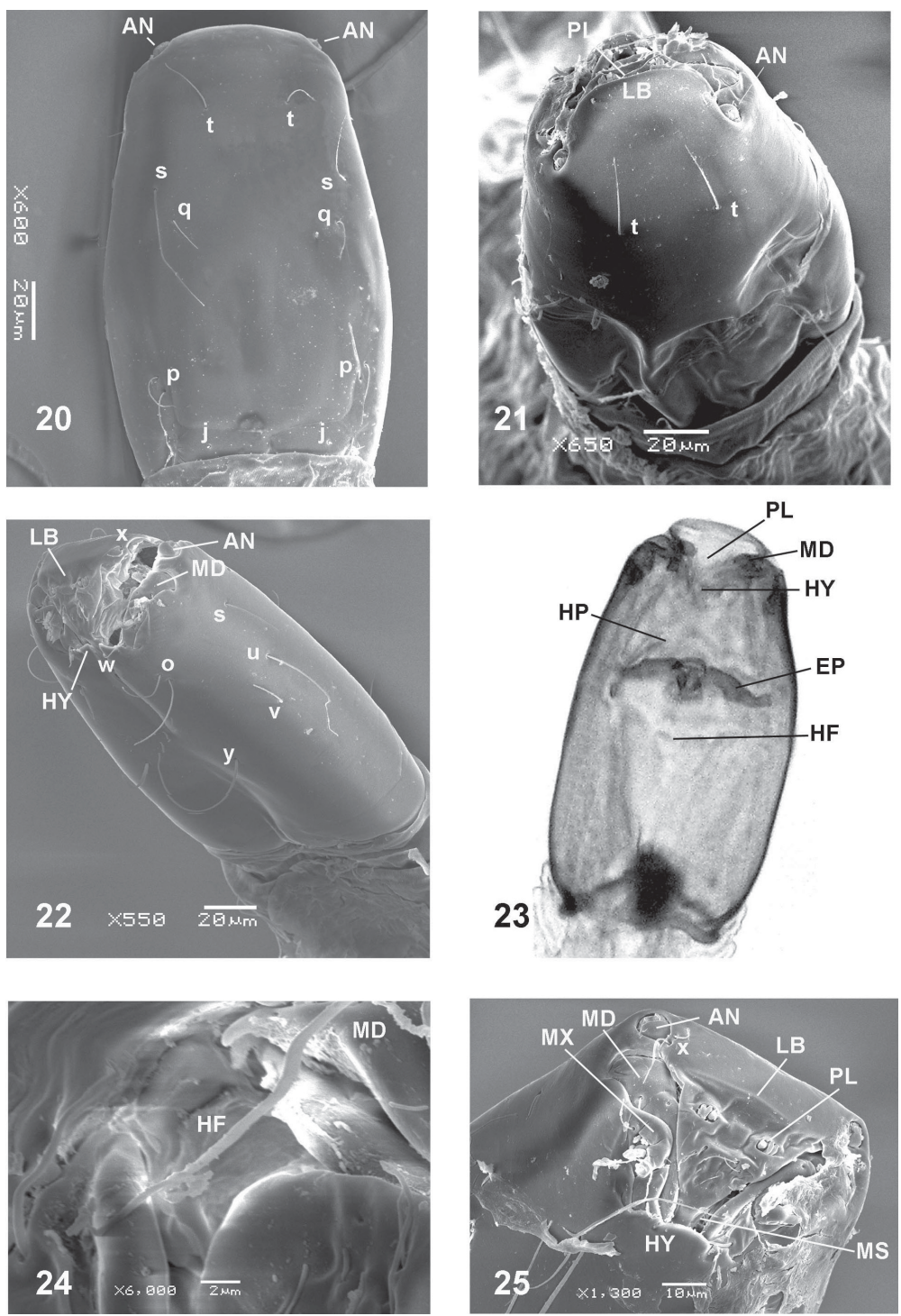

Culicoides felippebauerae, larva - Fig. 20: head capsule (dorsal view). Fig. 21: head capsule (anterodorsal view). Fig. 22: head capsule (lateroventral view). Fig. 23: head capsule (ventral, internal view). Fig. 24: head capsule (basal ventral, internal view). Fig. 25: head capsule (frontal view). Head capsule chaetotaxy: j: collar pits; p: posterior perifrontal setae; q: postfrontal setae; s: anterior perifrontal setae; t: prefrontal setae; o: parahypostomal setae; v: posterolateral setae; y: ventral setae; w: anterolateral setae; x: paranntenal setae; antennae (AN); epipharynx (EP); labrum (LB); hypopharynx (HP) hypostoma (HY); hypopharingeal fringe (HF); mandible (MD); messors (MS); maxilla (MX), palatum (PL).

male; Trinidad); Saunders, 1957: 660 (redescription; all stages; Trinidad).

Forcipomyia genualis: Johannsen, 1943: 777 (combination); Wirth, 1965: 125 (synonym: F. raleighi); Wirth, 1969: 575 (Galápagos islands record; distribution); Wirth \& Soria, 1975: 22 (redescription; distribution); Borkent, 1991: 104 (redescription, notes; Galápagos islands).

Forcipomyia (Forcipomyia) genualis: Wirth, 1974: 5 (in catalog; synonym: $F$. propinqua; distribution); Spinelli \& Marino, 1998: 39 (Argentina record).

Specimens examined - Brazil, Amazonas, Manaus, km 45 BR 174, 29-VII-2005, D Carrasco, 1 male; same data except km 95, 1 male.
Distribution - Widely distributed, from US (Louisiana to Florida) to Northern Argentina.

\section{Forcipomyia (Phytohelea) musae Clastrier \& Delécolle} (Figs 31-57)

Forcipomyia (Phytohelea) musae Clastrier \& Delécolle, 1994: 51 (male, female, pupa; French Guiana).

Redescription of pupa - Female: length 4.07 (3.66$4.52, \mathrm{n}=3) \mathrm{mm}$; exuviae pale yellowish. Cephalothorax length $1.37(1.28-1.46, \mathrm{n}=7) \mathrm{mm}$; width $0.93(0.82$ $1.02, \mathrm{n}=6$ ) $\mathrm{mm}$; cephalothoracic tubercles (Figs 31$33,44)$ as follows: anterodorsal tubercle (ad) short, blunt, without setae; dorsolateral tubercle (dl) strong, with one long, stout seta; dorsal tubercles (d) small: (i) 

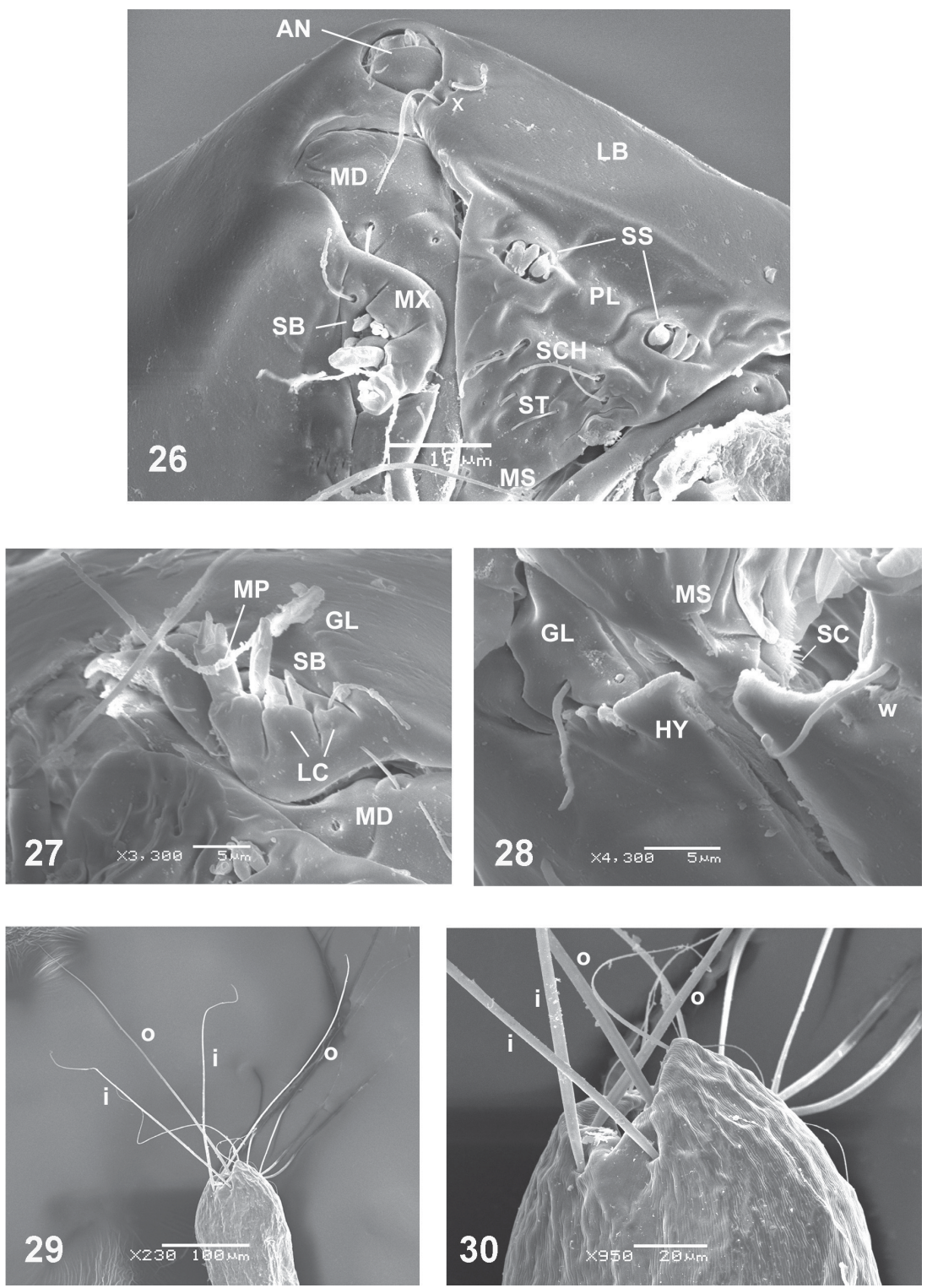

Culicoides felippebauerae, larva - Fig. 26: head capsule (frontal view). Fig. 27: maxilla. Fig. 28: messor, hypostoma, scopae. Fig. 29: caudal segment. Fig. 30: detail of caudal segment. Antennae (AN); galeolacinia (GL); hypostoma (HY); lacinial sclerites (LC); labrum (LB); mandible (MD); maxillary palpus (MP); messors (MS); maxilla (MX); palatum (PL); scopae (SC); sensilla basiconica (SB); sensilla chaetica (SCH); sensilla styloconica (SS); sensilla trichoidea (ST); w: anterolateral setae; x: paranntenal setae; caudal segment chaetotaxy: "o" outer setae, "i" inner setae.

with short, stout seta, (ii) with minute, stout seta, (iii) pore; one ventromedian (vm) medium length setae, thin, one pore. Respiratory horn (Figs 31, 45) length 0.20 $(0.19-0.22, \mathrm{n}=7) \mathrm{mm}$; amber brown, with scale-like spicules on basal half, with 13-14 apical spiracles; pedicel short, hyaline, length $0.025(0.022-0.028, \mathrm{n}=$ 7) $\mathrm{mm} ; \mathrm{P} / \mathrm{H} 0.12(0.11-0.14, \mathrm{n}=7)$. Operculum (Fig. 34) 0.5 as long as greatest breadth, apex broadly rounded; surface covered by rounded tubercles; anteromarginal tubercles (am) well developed, with single very short, stout seta; OL $0.17(0.15-0.18, \mathrm{n}=5) \mathrm{mm}$; OW 0.30 $(0.28-0.31, \mathrm{n}=5) \mathrm{mm}$; OW/OL $1.81(1.70-2.12, \mathrm{n}=5)$. Cephalothorax (Fig. 46) with four dorsal cuticular pro- cesses, two well developed (m3, m4), two rudimentary (m5, m6). Abdominal segments with scarse anterior spinules. Fourth abdominal segment (Fig. 35) with tubercles as follows: dorsal anterosubmarginal tubercle (dasm) with long, posteriorly directed seta, tuberculate broad base; dorsal posterosubmarginal tubercle (dpm) without seta, base elongate, triangular; lateral posteromarginal tubercle (lpm) with two setae, one long, one short, base broad tuberculate; four ventral posteromarginal tubercles (vpm): (i-ii) with medium length, strong seta, base triangular, (iii) with strong seta, base tuberculate, iv with thin seta, base poorly developed. Female caudal segment (Fig. 36) length 0.62 (0.56-0.67, 


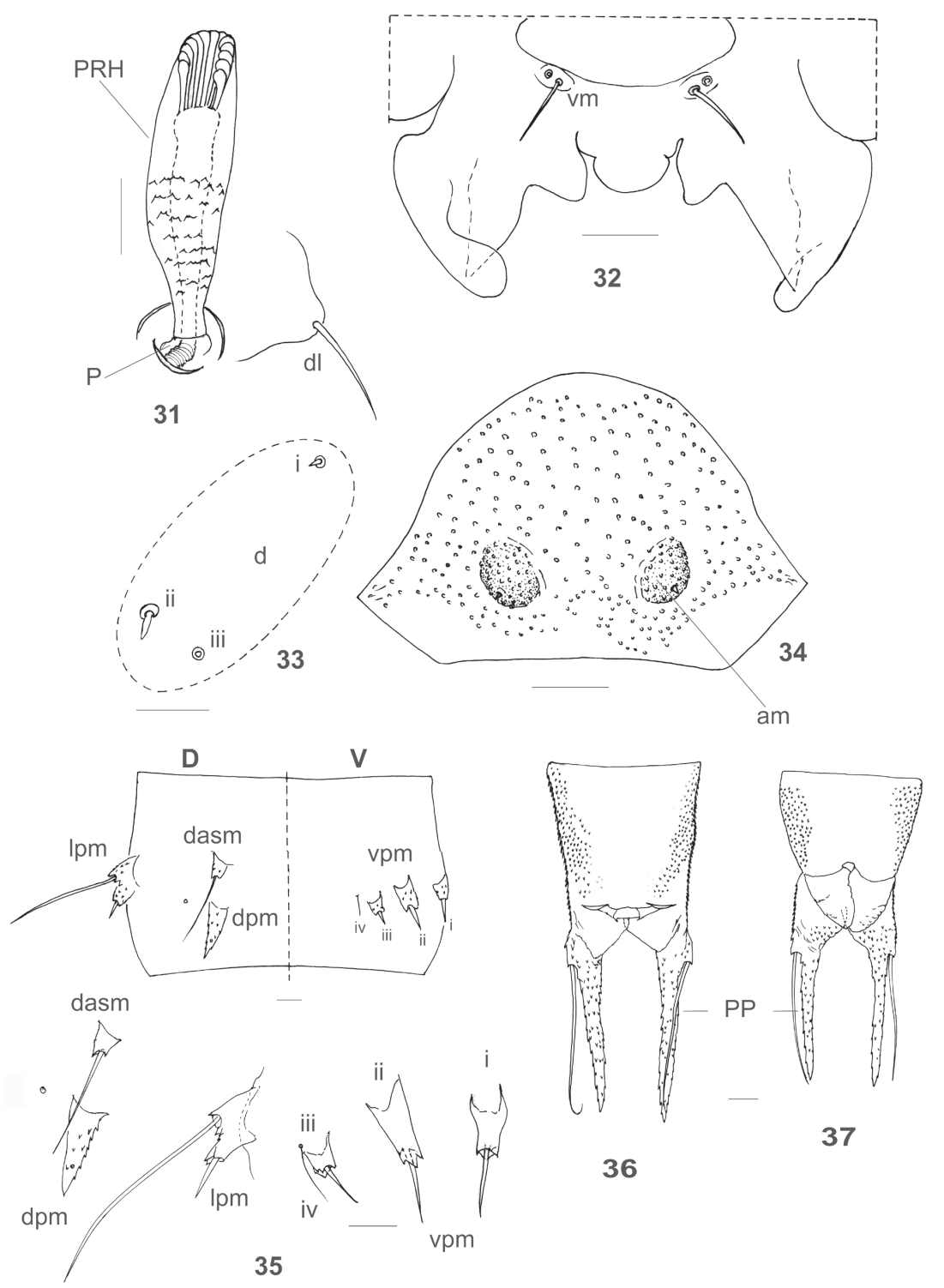

Forcipomyia (Phytohelea) musae, pupa - Fig. 31: dorsolateral tubercle (dl), respiratory horn (PRH), pedicel (P). Fig. 32: ventromedian setae (vm). Fig. 33: dorsal tubercles (d). Fig. 34: operculum, anteromarginal tubercle (am). Fig. 35: fourth abdominal segment, abdominal tubercles: dorsal anterosubmarginal tubercle (dasm), dorsal posteromarginal tubercle (dpm), lateral posteromarginal tubercle (lpm), ventral posteromarginal tubercle (vpm). Fig. 36: female caudal segment (ventral view). Fig. 37: male caudal segment (ventral view), posterolateral processes (PP).

$\mathrm{n}=4) \mathrm{mm}$, width $0.25(0.21-0.28, \mathrm{n}=4) \mathrm{mm}$, approximately two times longer than width; ventrolateral surface with band of posteriorly directed spicules; dorsal surface with posteriorly directed spicules except laterally and on a small, closed, mesal area; posterolateral processes long, tip pointed, base with outer long setae. Male caudal segment (Figs 37, 47) length 0.58 (0.54-0.60, $\mathrm{n}=3) \mathrm{mm}$, width $0.24(0.21-0.26, \mathrm{n}=3) \mathrm{mm}$. Genital processes ventral, stout, with distal wrinkles.

Description of larva - Exuviae pale brown. Head capsule brown, well developed, prognathous, HL 0.364 (0.288-0.392, n = 7) mm; HW 0.254 (0.192-0.312, n = 8) $\mathrm{mm}$; HR $1.394(1.256-1.50, \mathrm{n}=7)$; SGW $0.204(0.16-$
0.24, $\mathrm{n}=8) \mathrm{mm}$; SGR $1.24(1.20-1.31, \mathrm{n}=8)$. Antennae rounded, reduced. Head chaetotaxy (Figs 48-51) as follows: nine sensory setae, three pits; "j" pore simple; setae "p" short, thin; seta "q" long; seta "s" very long; seta " $t$ " as long than "q"; seta "v" long; "r" pore simple; setae "o" thin, one long, one short; seta " $u$ " long; setae " $x$ " minute, thin; seta "y" very long, stout; "z" pore simple. Labrum (Figs 48, 50-51) short, not extending beyond hypostoma; palatum (Figs 51-53) with a group of three sensillae styloconica on the outer edge, one posteromedial sensilla coeloconica; immediately underneath on medial surface two groups of three sensillae trichodea, one long, two short, one posterolateral sensilla coe- 


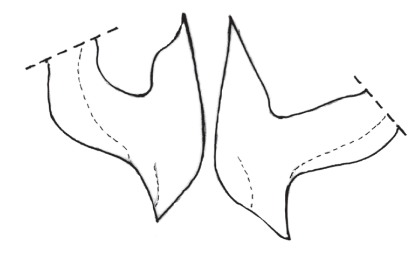

38

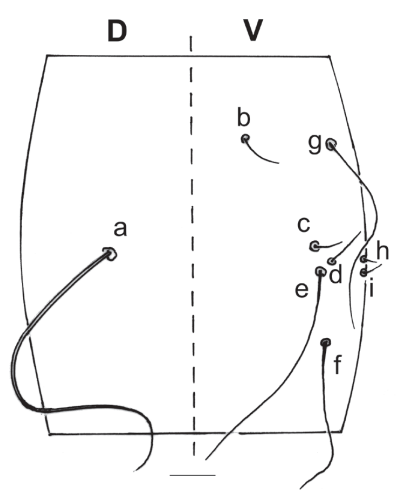

41

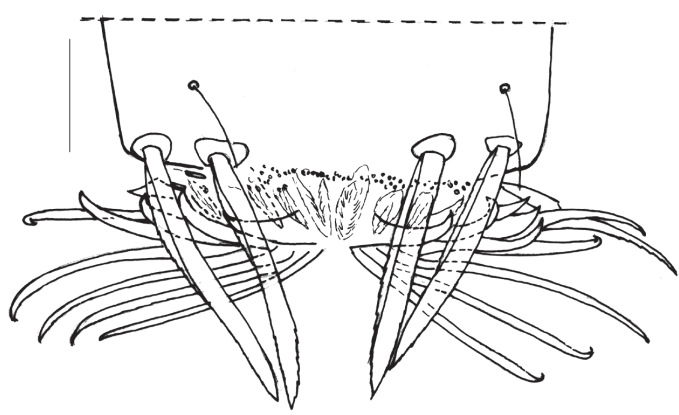

43

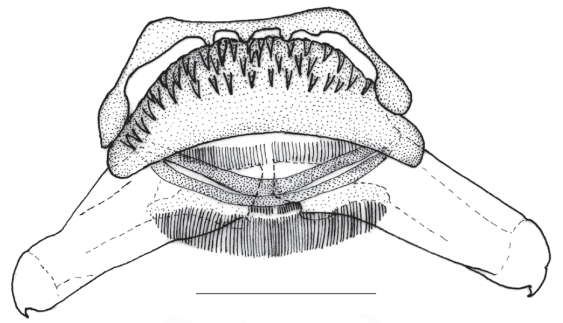

39
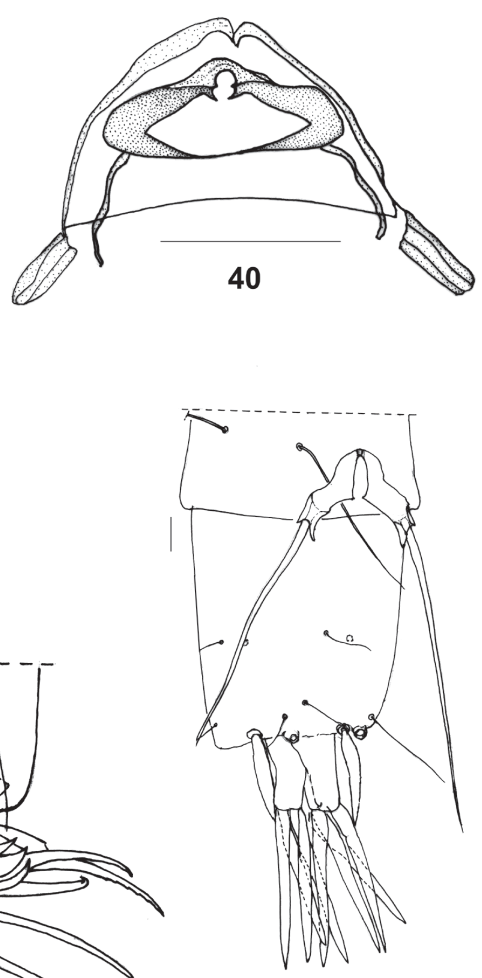

42

Forcipomyia (Phytohelea) musae, larva - Fig. 38: messors. Fig. 39: epipharynx. Fig. 40: hypopharynx. Fig. 41: setae of second abdominal segment. Fig. 42: eight abdominal segment and anal segment (dorsal view), anal papillae (ap). Fig. 43: peudopod of anal segment.

loconica, behind of these with tuft sensillae trichodea of different length. Messors (Fig. 38) stout, commashaped. Mandible (Figs 52-53) stout, not articulated with head capsule, with seven teeth, one apical, blunt, one subapical, truncate, posterior five elongated, slender, ML 0.089 (0.074-0.104, n = 8) mm; MW 0.032 (0.0260.044, n = 7) mm; hypostoma (Fig. 54) membranous, serrate. Epipharynx (Fig. 39) massive, strongly sclerotized, with median sclerite bearing numerous pointed, strong teeth; comb 3 with fringe; comb 2 with 20 small teeth; dorsal comb with approximately 40 fine teeth; lateral arms stout, with short apical teeth. LAW 0.154 (0.142-0.168, n = 6) mm; DCW 0.067 (0.064-0.074, n = 7) mm. Hypopharynx (Fig. 40) sclerotized, broad, lateral arms hyaline, thin. Maxilla bilobated (Figs 52-53, 55 ) with conspicuous basal fringe; galeolacinia with stout seta; maxillary palpus rounded, flattened, with four small papillae, lateral sclerite. Prothoracic pseudopod (Fig. 56) bifid, each ramus with two rows of eight golden thorn like hooks, 12-13 pairs of anterior hairs. Chaetotaxy of second abdominal segment (Fig. 41): dorsally, one seta "a" very long, stout, base poorly developed; ventrally, eight setae, three very long, thin, as long as dorsal seta ("e", "f", "g"), the other five ("b", "c" , "d", "h", "ii") very short, thin. Eigth abdominal segment (Figs 42, 57) bearing a very long dorsal setae measuring 0.42 (0.40-0.44, $\mathrm{n}=7) \mathrm{mm}$, arising from crossbar, surpassing the anal segment; cuticle devoid of spicules. Anal segment (Fig. 43) with four apical strong, blade-like setae, lateral margins serrate. Anal pseudopod with two rows of five pairs of laterally directed, sclerotized hooks, the ones of anterior row short, stout, with anteriorly recurved tips; 

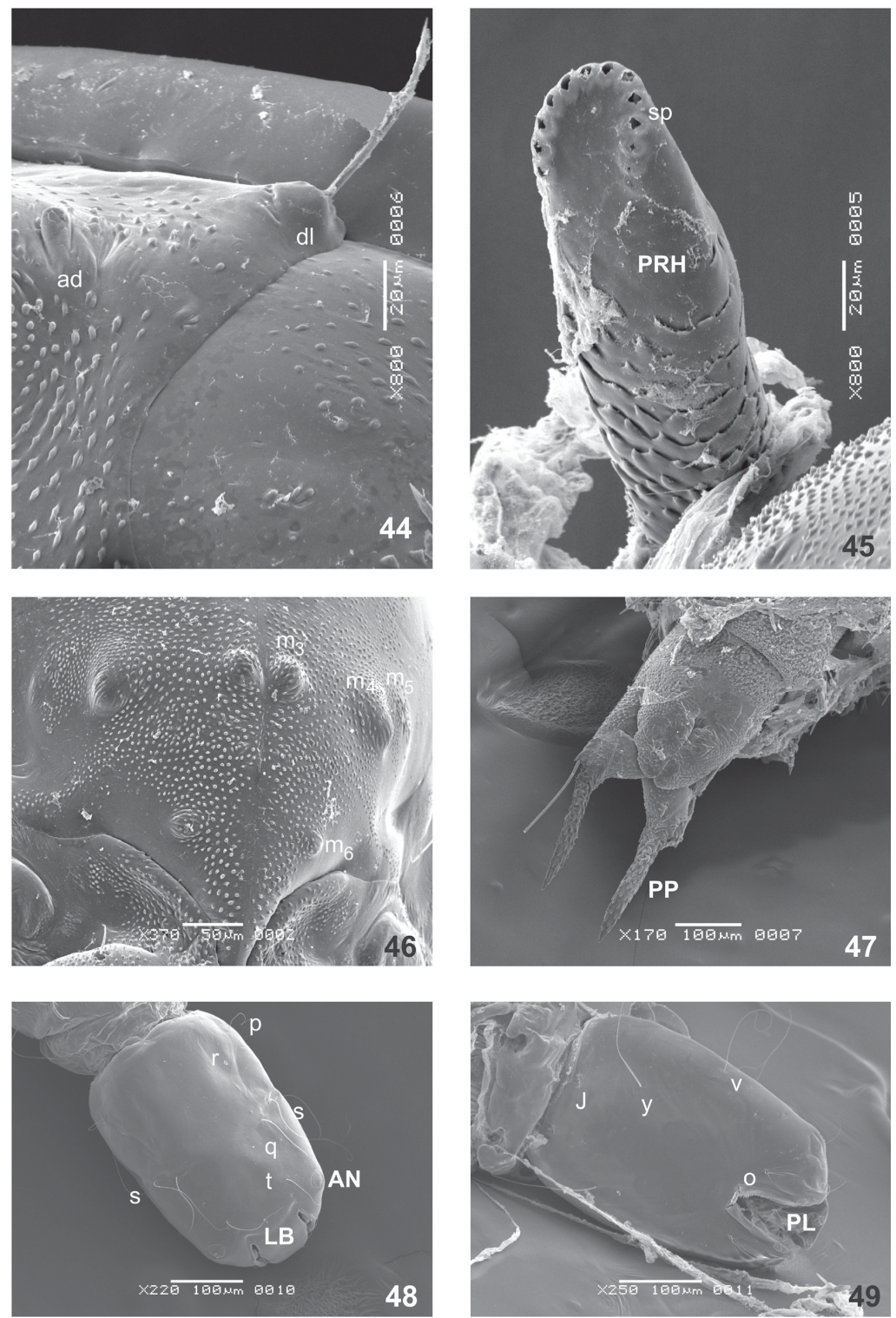

Forcipomyia (Phytohelea) musae - Figs 44-47: pupa. Figs 48-49: larva. Fig. 44: anterodorsal tubercle (ad), dorsolateral tubercle (dl). Fig. 45: respiratory horn (PRH), spiracles (sp). Fig. 46: dorsal cuticular processes (m3, m4, m5, m6). Fig. 47: male caudal segment (ventral view), posterolateral processes (PP). Fig. 48: head capsule (dorsal view). Fig. 49: head capsule (ventral view). Head capsule chaetotaxy: p: posterior perifrontal setae; q: postfrontal setae; r: frontal pits; s: anterior perifrontal setae; t: prefrontal setae; o: parahypostomal setae; v: posterolateral setae; $x$ : paranntenal setae; $y$ : ventral setae; antennae (AN); labrum (LB); palatum (PL).

hooks of posterior row elongated, slender, slightly paler. Anal papillae (Fig. 42) hyaline, bilobated, each lobe with two pairs of papillae; CSL $0.333(0.312-0.360, \mathrm{n}=7)$ $\mathrm{mm}, \mathrm{CSW} 0.264(0.224-0.296, \mathrm{n}=5) \mathrm{mm}, \mathrm{CSR} 1.304$ $(1.162-1.501, \mathrm{n}=5)$.

Specimens examined - Brazil, Amazonas, Manaus, km 31 BR 174, 2-IX-2005, D Carrasco, 1 female (with larval and pupal exuviae); same data, 1 male, 1 female (with pupal exuviae); same data except 14-VI-2006, 4 larvae; same data except km 123, 29-VII-2005, 2 males (with larval and pupal exuviae); same data, 1 male, $1 \mathrm{fe}$ male (with pupal exuviae); same data except $\mathrm{km}$ 95, 14VI-2006, 1 pupa, 1 larva.
Other specimens examined (preserved in alcohol $70 \%$ ) - Brazil, Amazonas, Manaus, 54 males (29 with pupal exuviae, 2 with larval exuviae), 55 females (31 with pupal exuviae, 1 with larval exuviae), 11 pupae, 7 larvae from the above mentioned localities and dates.

Material examined by SEM - Brazil, Amazonas, Manaus, km 95 BR 174, 14-VI-2006, D Carrasco, 7 pupae, 7 larvae.

\section{Distribution - Brazil (Amazonas), French Guiana.}

Taxonomic discussion - This species belongs to the $F$. bromelicola species group, as defined by de Meillon and Wirth (1979). It keys out to couplet 5 in de Meillon and Wirth (1979), where it may be distinguished from $F$. 

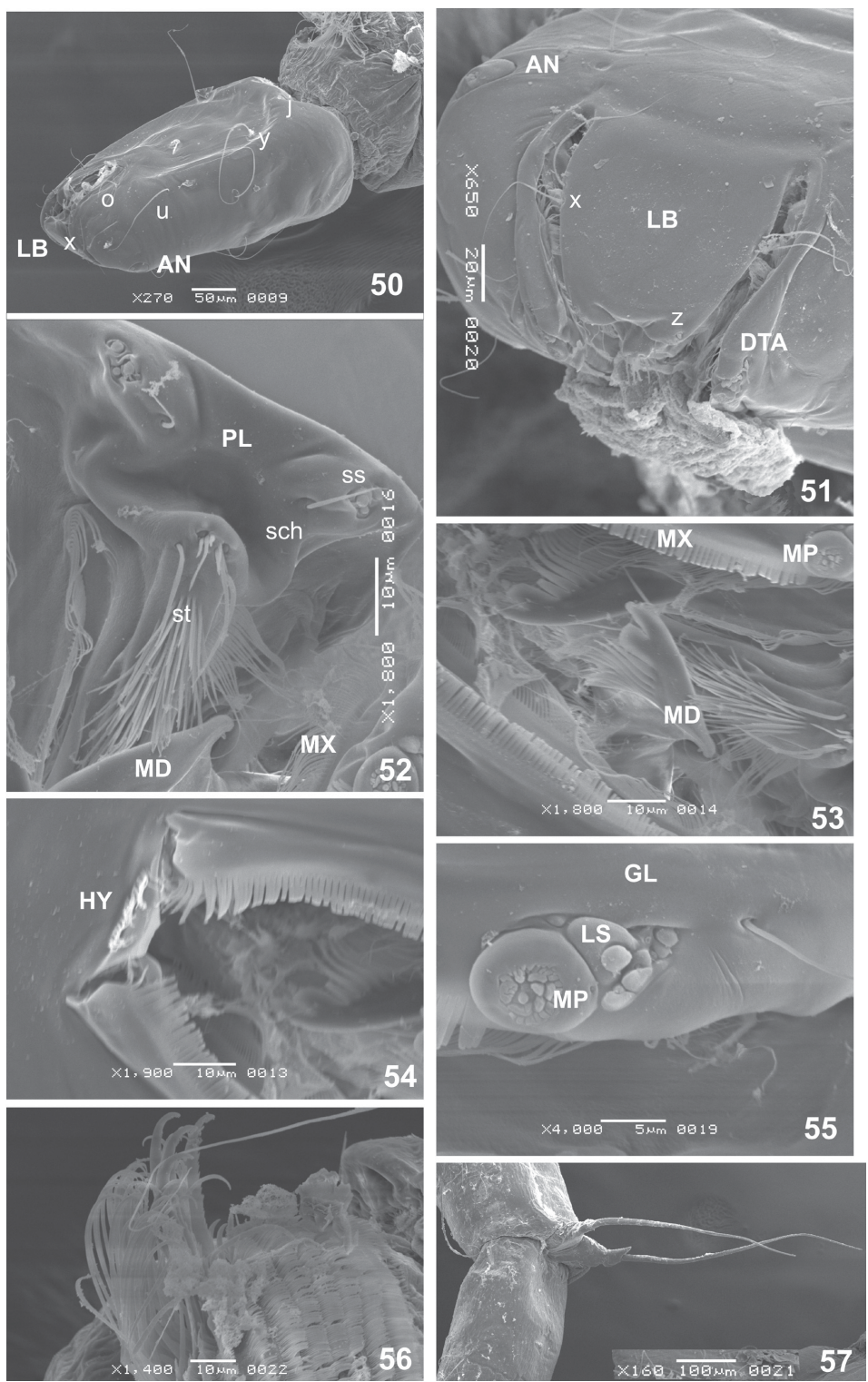

Forcipomyia (Phytohelea) musae, larva - Fig. 50: head capsule (lateroventral view). Fig. 51: head capsule (frontal view). Fig. 52: head capsule (ventral view). Fig. 53: detail of head capsule (ventral view). Fig. 54: maxilla, hypostoma. Fig. 55: detail of maxilla. Fig. 56: prothoracic pseudopod. Fig. 57: eight abdominal segment. Head capsule chaetotaxy: j: collar pits; o: parahypostomal setae; u: mesolateral setae; x: paranntenal setae; y: ventral setae; z: frontal pits; antennae (AN); dorsal tentorial arms (DTA); galeolacinia (GL); hypostoma (HY); lateral sclerite (LS); labrum (LB); mandible (MD); maxillary palpus (MP); messors (MS); maxilla (MX); palatum (PL); sensilla chaetica (SCH); sensilla styloconica (SS); sensilla trichoidea (ST); hooks.

(Phytohelea) edwardsi (Saunders) from Brazil, by the slightly unequal sized, pyriform spermathecae with sclerotized necks (subequal sized, subspherical with unsclerotized necks in F.edwardsi). The male genitalia of $F$. musae are also very similar to those of $F$. edwardsi, but can be distinguished from the later species by the gonostylus shorter than gonocoxite (subequal in $F$. edwardsi), and by the recurved posterior processes of parameres (spoon-like in $F$. edwardsi). Immatures of $F$. edwardsi can be distinguished from immatures of $F$. musae by the respiratory horn of the pupa expanded laterally and bearing 12 apical spiracles (not expanded, with 14 apical spiracles in F. musae), by the larger head ratio
(HR) of the larvae, and by the larval lateral setae with basal fin-like expansions (without these expansions in F. musae).

Adults of this species also resemble $F$. bromelicola (Lutz) by virtue of their similar male genitalia, but differ from this species by the following characters: female palpus with subapical sensory pit (at midlength in $F$. bromelicola), humeral areas and scutellum pale (brown in F. bromelicola) and pyriform spermathecae with sclerotized neck (elliptical with unsclerotized neck in F. bromelicola). The description of the larva and pupa of $F$. bromelicola by Saunders (1925) is very incomplete, and therefore it is very difficult to compare the immature stages of both species. 


\section{ACKNOWLEDGMENTS}

To Dr William Grogan for detailed critical review of the manuscript acting as a journal referee.

\section{REFERENCES}

Borkent A 1991. The Ceratopogonidae (Diptera) of the Galápagos Islands, Ecuador with a discussion of their phylogenetic relationships and zoogeographic origins. Entomol Scan 22: 97-122.

Borkent A, Spinelli GR 2000. Catalog of the New World biting midges south of the United States of American (Diptera: Ceratopogonidae). Contrib Entomol Intern 4: 1-107.

Clastrier J, Delécolle JC 1994. Description de Forcipomyia (Phytohelea) musae n. sp. de la Guyane francaise (Diptera, Ceratopogonidae). Rev Franc Entomol 16: 51-56.

De Meillon B, Wirth WW 1979. A taxonomic review of the subgenus Phytohelea of Forcipomyia (Diptera: Ceratopogonidae). Proc Entomol Soc Wash 81: 178-206.

Díaz F, Ronderos MM, Spinelli GR 2005. The immatures of the Neotropical species Culicoides venezuelensis Ortiz \& Mirsa (Diptera: Ceratopogonidae). Trans Am Entomol Soc 131: 375-385.

Fish D 1976. Structure and Composition of the Aquatic Invertebrate Community Inhabiting Epiphytic Bromeliads in South Florida and the Discovery of an Insectivorous Bromeliad, Ph D Thesis, University of Florida, Gainesville, 78 pp.

Fish D 1983. Phytotelmata: flora and fauna. In JH Frank, LP Lounibos, Phytotelmata: Terrestrial Plants as Hosts of Aquatic Insect Communities, Plexus, Medford, p. 161-190.

Fish D, Soria SJ 1978. Water-holding plants (Phytotelmata) as larval habitats for ceratopogonid pollinators of cacao in Bahia, Brazil. Revta Theobroma 8: 133-146.

Johannsen OA 1943. A generic synopsis of the Ceratopogonidae (Heleidae) of the Americas, a bibliography, and a list of the North American species. Ann Entomol Soc Am 36: 763-791.

Loew H 1866. Diptera Americae septentrionalis indigena. Berl Entomol Zeits 9: 127-186.

Macfie JWS 1938. Notes on Ceratopogonidae (Diptera). Proc $R$ Entomol Soc London (B) 7: 157-166.

McAlpine JF, Peterson BV, Shewell GE, Teskey HJ, Vockeroth JR, Wood DM 1981. Manual of Nearctic Diptera, Vol. 1, Agriculture, Monograph 27, Canada, 674 pp.

Mercer DR, Spinelli GR, Watts DM, Tesh RB 2003. Biting rates and developmental substrates for biting midges (Diptera: Ceratopogonidae) in Iquitos, Peru. J Med Entomol 40: 807-812.

Mullen GR, Hribar LJ 1988. Biology and feeding behavior of Ceratopogonidae larvae (Diptera: Ceratopogonidae) in North America. Bull Soc Vector Ecol 13: 60-81.

Murphree CS, Mullen GR 1991. Comparative larvae morphology of the genus Culicoides Latreille (Diptera: Ceratopogonidae) in North America with a key to species. Bull Soc Vector Ecol 16: 269-399.
Ribeiro JELS, Hopkins MJG, Vicentini A, Sothers CA, Costa MAS, Brito JM, Souza MAD, Martins LHP, Lohmann LG, Assunçao PACL, Pereira EC, Silva CF, Mesquita MR, Procópio LC 1999. Flora da Reserva Ducke. Guia de Identificação das Plantas Vasculares de uma Floresta de Terra-firme na Amazônia Central, 19th ed., INPA-DFID, Manaus, $816 \mathrm{pp}$.

Ronderos MM, Spinelli GR 2000. The larvae and pupa of Culicoides bambusicola Lutz observed with SEM, and additional notes on the adults (Diptera: Ceratopogonidae). Trans Am Entomol Soc 126: 133-144.

Saunders LG 1925. On the life history, morphology and systematic position of Apelma Kieff. and Thyridomyia n. g. (Diptera, Nemat. Ceratopogoninae). Parasitology 17: 252-277.

Saunders LG 1957. Revision of the genus Forcipomyia based on characters of all stages (Diptera, Ceratopogonidae). Canad J Zool 34: 657-705.

Spinelli GR, Marino PI 1998. First records for Argentina of three species of Forcipomyia (Diptera : Ceratopogonidae). Revta Soc Entomol Argent 57: 39-40.

Spinelli GR, Marino PI, Ronderos MM 2005. The fourth instar larva and pupa of the Neotropical species Forcipomyia (Forcipomyia) rioplatensis Marino \& Spinelli (Diptera: Ceratopogonidae). Proc Entomol Soc Wash 107: 108-114.

Szadziewski R 1996. Biting midges from Lower Cretaceous amber of Lebanon and Upper Cretaceous Siberian amber of Taimyr (Diptera, Ceratopogonidae). Studia Dipterol 3: 23-86.

Vitale GC, Wirth WW, Aitken THG 1981. New species and records of Culicoides reared from arboreal habitats in Panama, with a synopsis of the debilipalpis group (Diptera: Ceratopogonidae). Proc Entomol Soc Wash 83: 140-159.

Williston SW 1896. On the Diptera of St. Vincent (West Indies). Trans Entomol Soc London 1896: 253-446.

Winder JA 1977. Some organic substrates which serve as insect breeding sites in bahian cocoa plantations. Revta Brasil Biol 37: 351-356.

Wirth WW 1965. Family Ceratopogonidae. In A Stone, A Catalog of the Diptera of America North of Mexico, Agriculture Handbook 276, Washington, D.C., p. 121-142.

Wirth WW 1969. New species and records of Galapagos Diptera. Proc Calif Acad Sci 36: 571-594.

Wirth WW 1974. Family Ceratopogonidae. In A Catalogue of the Diptera of the Americas South of the United States, Fasc. 14, 89 pp.

Wirth WW, Soria SJ 1975. A new Neotropical Forcipomyia midge closely related to $F$. $(F$.) genualis (Loew) (Diptera: Ceratopogonidae). Revta Theobroma 5: 19-27.

Wirth WW, Soria SJ 1981. Two Culicoides biting midges reared from inflorescences of Calathea in Brazil and Colombia, and a key to the species of the discrepans group (Diptera: Ceratopogonidae). Revta Theobroma 11: 107-117. 